\title{
Perspectives of Architects on Obstacles of Sustainable Architecture in Metropolitan Areas of Iran
}

\author{
Jalal Salek Zamankhani ${ }^{1}$
}

\begin{abstract}
In the era of ecological and economic crises all over the world, while the trend has drastically changed, most buildings in the developing countries are still built in a conventional way. The problem has roots in the fact that ecologically sustainable buildings are often initially challenging in design process and more costly compared to ordinary ones. On the other hand, there has been little research discussing the impact of sustainable architecture trend on real estate benefits and marketing of the buildings. Yet a lack of research investigating the importance of architecture in the marketplace of sustainable or green buildings especially high-rise ones is evident. This study presented current literature on sustainable architecture and an analysis of the building appraisal process in different locations and mainly in Iran with special attention to the perspective of architects active in high-rise construction.
\end{abstract}

Keywords: architect, building, green, sustainable.

\section{Introduction}

There are over two hundred definitions available for sustainability and the most prominent related to the built environment entailing architecture is the Brundtland Report in which sustainable development addresses the needs of the present without comprising the needs of future generations. Therefore, buildings that are built efficiently with a minimum negative impact on the surrounding environment during their construction and life cycle are considered sustainable.

There is almost no doubt in the importance of sustainable architecture. However, there are some obstacles in the way of its dominance. For example sustainable homes are believed to cost more to construct and generally clients are unwilling to initially invest more to purchase them. These are primary reasons that investors are usually hesitant to invest in sustainable projects. According to a McGraw-Hill Smart Market Report, higher upfront cost is one of the main restraints in increase of green building activity. In addition, the industry is more experienced in conventional housing making that approach relatively less risky and more desirable (Fadaei et al., 2015).

In an attempt to address these issues and problems and to pave the way for achievement of sustainable architecture, the building industry in many countries has begun to implement green building methods and technologies. To achieve benefits of green building, the project team needs to shift to more integrated processes in all phases of a building's life cycle (Larsson, 2009). Tasks in green building are not completed by a single action or entity but require a multidisciplinary team approach and the 
implementation of iterative processes during the building's design and construction. At the construction phase, careful attention must be devoted to both design strategies and construction opportunities for ensuring that a project is delivered in a sustainable fashion. To successfully implement green strategies and technologies during the construction phase, a range of green strategies and technologies can be deployed to achieve the goals of green building. Construction opportunities here include preconstruction services, minimizing site disturbance, erosion and sedimentation control, pollution prevention, sustainable site operation, construction waste management, indoor air quality management, green materials management, and commissioning, among others (Pearce et al., 2012; Frattari et al., 2012; Ahn et al., 2016). This paper was an attempt to present an empirical study on the obstacles of sustainable architecture implementation in Iran focusing on the perspective of professional architects and designers. This study is of importance for architects and designers as well as policy makers and developers active in design and construction of buildings in larger scales including high-rise buildings. This paper can be used as a tool or database for documentation of sustainable design characteristics on contemporary architecture of Iran being useful for production of suitable guidelines in designing better and more sustainable buildings with higher standards in the future.

\section{The Necessity of Sustainable Architecture}

In most academic and professional documents, a green building is a building with high energy efficiency that is reflected in the environmental aspect and is usually used as a synonym to sustainable building. Although the green or sustainable building and technology movement is still in its early stages, some expect that it will inspire influential innovations and transformations for human society as daunting as the changes brought about by information technology during the last two decades. In a general view, sustainable building features are usually summarized into seven major categories:

- Minimal disturbance to environment, surrounding landscapes and site conditions.

- Use of non-toxic, reuse and recycle of materials.

- Efficient use of water sources and provision of water recycling.

- Use of energy efficient and eco-friendly equipment and installations.

- Use of renewable energy and materials.

- Provision of high quality indoor air suitable for human safety and comfort.

- Effective monitoring, control and management systems in building.

Among the above-mentioned categories, energy consumption is much more significant and influential. Energy consumption in urban areas accounts for about $75 \%$ of the global total, and more than $80 \%$ of the total carbon emissions (Stern, 2007). In addition, the construction sector consumes over $40 \%$ of the raw materials, and contributes $40 \%$ to $50 \%$ of the greenhouse gas emissions. In the European Union, the energy demand of construction sector has accounted for more than $40 \%$ of the total demand (Mistretta \& Fulvio, 2011; Huang et al., 2016). Emissions from construction material predominate the total emission from construction process of a building.

In Iran, a large number of studies have discussed the effect of sustainable technologies on spatial qualities mostly focusing on urban sustainability and role of urban gardens and 
open spaces and even linking it to social features. While others have discussed the role of sustainable architecture in achievement of human comfort in interior spaces or its impact on perception of architectural space, little attention has been given to the design aspect of sustainable buildings. Many efforts to define and measure environmentally responsible building design, various rating systems have been developed since 1990's. The term 'green Architecture' has been a synonym for environmentally responsible architecture since the 1970's. Building that is environmentally responsible has come to be called "green building" both in the building professions and in the popular culture. Since the term of sustainability usually is concerned with environmental aspects, even implementation for such concept can change the community overall life style and here is the challenge faced most of the region countries in a social level they had to get rid of certain traditions and old thinking to face the new era that witnessed running out the earth of its natural resources, specially energy resources; where the education and new generation have to follow the way of sustainability (Ibrahim, 2017). Conventionally, the following discussions have been related to the idea of sustainable architecture from the energy point of view in Iran (Table 1).

Table 1: Different aspects of sustainable energies in Iran

\begin{tabular}{|c|c|}
\hline Types of Resources & Potential Prospect \\
\hline Solar Power & $\begin{array}{l}\text { Iran enjoys plenty of sunshine all year round with consistent radiance. } \\
\text { Global costs of solar energy collection are coming down annually. }\end{array}$ \\
\hline Wind & $\begin{array}{l}\text { Marginal cost for the wind power technology develops but } \\
\text { inconsistency in wind speed limits the development. The wind does not } \\
\text { blow uniformly in some areas. }\end{array}$ \\
\hline Hydro & $\begin{array}{l}\text { Increasing cost for overhead and underground transmission, but have } \\
\text { potential competitive energy generating capacity in different zones of } \\
\text { Iran. Issues on environmental impacts sometimes leads to relocation of } \\
\text { native and local residents. }\end{array}$ \\
\hline Geothermal & $\begin{array}{l}\text { Just found recently in some areas of Iran. Localized energy, with the } \\
\text { potential to generate up to } 67 \mathrm{MW} \text { of } \\
\text { electricity per day to meet the energy needs of metropolises. }\end{array}$ \\
\hline $\begin{array}{l}\text { Biomass/Biogas/ } \\
\text { Waste }\end{array}$ & $\begin{array}{l}\text { Substantial resources from some natural sources, rubber plantation } \\
\text { throughout the country and timber waste from natural rainforests across } \\
\text { country. Land used planning and development need to be considered } \\
\text { and high carbon reduction compared to solar and wind energy. }\end{array}$ \\
\hline Nuclear & $\begin{array}{l}\text { Technology still not fully developed in Iran and facing international } \\
\text { problems. At the moment, only limited amount of electricity is } \\
\text { generated in small reactors. Detailed study and development programs } \\
\text { should be carried out pertaining to issues on national and international } \\
\text { policies. }\end{array}$ \\
\hline $\begin{array}{l}\text { Energy-Efficiency } \\
\text { (EE) }\end{array}$ & $\begin{array}{l}\text { Need to be implemented throughout the country especially in } \\
\text { commercial building in metropolitan areas in Iran. Architects need to } \\
\text { pay much more attention in implementing EE in design and } \\
\text { construction. }\end{array}$ \\
\hline $\begin{array}{l}\text { Ocean } \\
\text { (Wave/Tidal) }\end{array}$ & $\begin{array}{l}\text { Technology is not fully developed in Iran and there is little potential to } \\
\text { harness wave/tidal energy } \\
\text { because the wave power density of Iranian ocean is not enough. }\end{array}$ \\
\hline
\end{tabular}


In recent years, sustainability is no more an optional idea, it has become a major requirement to sustain certain level of quality of life for the coming generation especially in urban areas. Therefore, developing new rating systems by governments assuring their responsibilities towards the social needs of community and the environmental requirements of the society have become international demand pushing the developing countries to create their own rating systems serving the communities in a better way. We can notice clearly many rating systems used in the Asian countries, some of them are international and the rest are developed to match each country's unique conditions considering the three pillars of sustainability; the environment, economy and society. Some of the most significant rating systems for sustainable building in Asian countries are summarized in Table 2 .

Table 2: Summary of rating systems for sustainable building

\begin{tabular}{|c|c|c|c|}
\hline Rating System & Type of Certification & Managing Organization & Areas of Focus \\
\hline $\begin{array}{l}\text { The Global } \\
\text { Sustainability } \\
\text { Assessment System } \\
\text { (GSAS) }\end{array}$ & $\begin{array}{l}\text { Green Building rating } \\
\text { system }\end{array}$ & $\begin{array}{l}\text { Gulf Organization for } \\
\text { Research and Development } \\
\text { (GORD) in Qatar }\end{array}$ & $\begin{array}{l}\text { GSAS certification is } \\
\text { divided into eight } \\
\text { different categories: } \\
\text { - Energy } \\
\text { - Water } \\
\text { - Indoor Environment } \\
\text { - Cultural \& Economic } \\
\text { Value } \\
\text { - Site } \\
\text { - Urban Connectivity } \\
\text { - Material } \\
\text { - Management \& } \\
\text { Operation }\end{array}$ \\
\hline $\begin{array}{l}\text { ARZ Green } \\
\text { Building Rating } \\
\text { System }\end{array}$ & $\begin{array}{l}\text { Non-Profit organization } \\
\text { but it has been achieved } \\
\text { in cooperation with IFC, } \\
\text { a member of the World } \\
\text { Bank Group, as an } \\
\text { international } \\
\text { consultants. }\end{array}$ & $\begin{array}{l}\text { The Lebanese Green } \\
\text { Building Council (LGBC) } \\
\text { in Lebonan }\end{array}$ & $\begin{array}{l}\text { ARZ system has eight } \\
\text { modules for assessment: } \\
\text { - Energy Performance } \\
\text { - Thermal Energy } \\
\text { - Electrical Energy } \\
\text { - Building Envelope } \\
\text { - Materials } \\
\text { - Indoor Air Quality } \\
\text { - Water Conservation } \\
\text { - Operations and } \\
\text { Management }\end{array}$ \\
\hline $\begin{array}{l}\text { Pearl Rating System } \\
\text { (Estidama) }\end{array}$ & $\begin{array}{l}\text { Green Building rating } \\
\text { system using Pearls } \\
\text { System for: } \\
\text { - Community } \\
\text { - Buildings } \\
\text { - 3. Villas }\end{array}$ & $\begin{array}{l}\text { Abu Dhabi Urban Planning } \\
\text { Council in UAE }\end{array}$ & $\begin{array}{l}\text { Assessment of } \\
\text { performance in: } \\
\text { - Integrated } \\
\text { Development Process } \\
\text { - Natural systems } \\
\text { - Liveable communities } \\
\text { - Precious water } \\
\text { - Resourceful energy } \\
\text { - Stewarding Materials } \\
\text { - Innovating practice }\end{array}$ \\
\hline
\end{tabular}




\section{Research Methodology}

In this research, there were two main phases in the data acquisition process. The first phase was the accumulation of raw data through intensive reading of sources and references including research journals and conference proceedings about sustainability in general and sustainable building in particular including energy consumption as well as sustainable design and construction technologies. This study was conducted through the qualitative approach in which a unique technique of data interpretation is created to explain the real meaning of the studied subjects. Besides, face-to face and semistructured interviews have been used as the main method, while the secondary method is more on observations of the high-rise projects. The series of interviews were conducted on one hundred (100) participants (all of them are architects from Tehran, Tabriz and Isfahan who have designed high-rise buildings). The interview process was guided with an instruction and also a facilitator. The interview guide was constructed based on previous studies and researches, mainly done by Turner Construction report (Turner, 2005) and McGraw Hill construction report 2005 (Cryer et. al., 2006). The preliminary interview guide was validated by three (3) experienced persons in sustainable architecture areas including (i) a professor of climate, energy and environmental research in Tehran University (ii) an architect experienced in green and sustainable technologies, and (iii) a developer interested in sustainable architecture, design and construction and technology. Each interview took approximately 45 to 60 minutes and it was also digitally recorded for greater precision. Besides, researchers also collected some data including pictures of the buildings designed or under construction as well as newly proposed projects.

\section{Analysis of Findings}

The main objective of this research was to understand the level of awareness of those architects active in design and construction of large scale buildings in Iran towards adoption of sustainable technologies into design and construction of buildings. This study managed to get one hundred respondents (mainly architects and designers) and all of the interviews were conducted within a one week period.. Each interview was digitally recorded and transcripted within one working week and then the transcriptions were emailed to the respondents for validation purposes.

There were one hundred respondents that were selected by random from formal list of architects who have designed high-rise buildings mostly offices and commercial ones and were involved via semi-structured face-to-face interviews. On average, all of them are involved in the mainstream activities of high-rise building design and construction businesses between 10 to 20 years. When they were asked about awareness of sustainable buildings in Iran, most of them were aware and realized (77\%) that sustainable building technologies should be applied in the high-rise constructions presently, and this adaptation will bring a lot of green benefits for future generations living in urban areas. The concern about values of environmental issues is also encouraged since they are now guided by numerous academic and governmental programs. Some of them $(55 \%)$ have been involved in several Research \& Marketing programs. In making green technologies into construction of high-rise buildings, all respondents had different opinions about 
perceived obstacles encountered in their career. There are nine main and perceived obstacles including lack of technology and knowledge transfer, lack of awareness, not applicable now, little incentives from authorities, being too complicated, not comfortable, hard to justify, potential buyers not willing to pay for the technology and extra costs, which have been concluded from the interviews and opinions of respondents. The percentage of each obstacle is displayed in the Figure 1.

\section{Obstacles of sustainable architecture from perspective of architects}

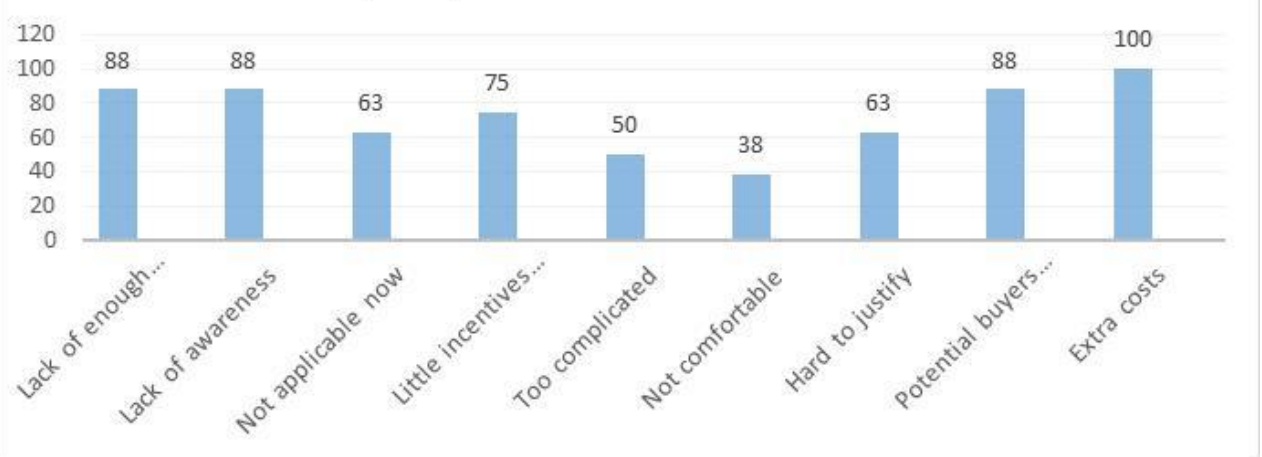

Fig. 1: Perceived obstacles of sustainable architecture from perspective of architects

This study revealed that first, all respondents agree that the lack of technology transfer and the knowledge of developed countries like the United States of America and Australia have prevented the local high-rise architects to embrace green technologies into their design tasks. This indicates that there is not much collaboration between them in terms of design and construction projects. Therefore, the impact of transferring technology and knowledge will limit to upgrade the level of high-rise buildings with green or sustainable technologies. Second, Iranian architects have been facing the limitation of financial incentives in order to upfront the green technologies cost into the initial program of high-rise development recently. There can be a few significant reasons for this obstacle including;

a) Presently there is too little exposed results about green technologies embedded into high-rise building from the perspective of those who pay for the office units (buyers), developers and owners or investors of the projects,

b) Buyers of course are not ready to purchase the units at a premium price because the present price is normally expensive. And

c) Government should offer a bunch of financial incentives in terms of promotions or some novel strategies, for example significant exemptions of tax or less interests for bank loans and other financial aids.

During the interviews, all respondents were asked to give some recommendations about some of major factors that will support to flourish the sustainable architecture as well as green technology adoption for high-rise projects in metropolitan areas of Iran. The results obtained from the respondents as they assume some of the major factors can be 
summarized as follows:

a) A set of strong commands from local governmental agencies affecting construction industry such as municipality as well as some private organizations related to the industry,

b) A significant growth in demand of potential high-rise unit buyers to save some costs for long term period,

c) An increase in number of potential high-rise unit buyers via responsible spending to save the nature and environment,

d) An increase in number of people who do their best for future generations, and

e) An increase in amount of investments of potential investors and developers for the achievement of healthy conditions in buildings.

\section{Conclusions}

As it is implied from the literature reviewed above, many studies have attempted to connect "sustainability," on one hand, and "architectural design," on the other, to higher benefits in property value. Most of these however, are focused on commercial high-rise buildings and less attention has been given to the attitude of architects. In addition, since the subject of sustainability is a rapidly evolving one in developing nations like Iran, a lot of the existing literature is outdated and needs to be revised or reassessed and the localized.

Finall, it is obvious that dominant or successful buildings of the future must not merely be measured by total height and floor area, but instead by their sustainability, efficiency and impact on surrounding environment. Previous researches mostly have indicated that future trends in architectural design in Iran will encompass mixed-use prototype in large scale projects and will affect the environment more than before. Therefore, one of the key items in success of future sustainable buildings will be the viewpoint of architects and designer towards integration environmentalist approach and green technologies into design and construction process. The main results of this study combined the results achieved from previous studies emphasize the two following recommendations for achievement of sustainable architecture;

(a) sustainable building technologies are now in novelty phase in Iran and a robust awareness and collaboration between all players in the construction industry including clients, developers, urban managers and architects is necessary, especially in metropolitan areas,

(b) and (b) governmental incentives are needed intensely in providing more promotions and financial supports for adopters of more sustainable buildings, sustainable technologies and materials, renewable energies and energy-efficient ideas as the design concept for large scale buildings.

\section{References}

Ahn, Y. H. \&. Pearce, A.R (2007). Green construction: contractor experiences, expectations and perceptions. Journal of Green Building, 2(3), 106-122.

Ahn, Y. H., Woo Jung, Ch., Suh, M., \& Hwa Jeon, M. (2016). Integrated construction process for green building, Procedia Engineering, 145 ( 2016 ) 670 - 676. 
Badri Benam, N. \& Moosavi, M.S. (2012). An architectural approach to characterization of modern healthcare environments, J. Appl. Environ. Biol. Sci., 2(9)460-465.

Cryer, B., Felder, J., Matthews, R., Pettigrew, M., \& Okrent, B. (2006). Evaluating the diffusion of green building practices. Available at: http://personal.anderson.ucla.edu/charles.corbett/papers.

Fadaei, Sh., Iulo, L. D., Yoshida, J. (2015). Architecture: A missing piece in real-estate studies of sustainable houses, Procedia Engineering, 118 (2015), 813-818.

Huang. W., Fei, L., Cui, H., Huang, L., Lin, J. (2017). Carbon footprint and carbon emission reduction of urban buildings: A case in Xiamen City, China. Procedia Engineering, 198 (2017), 1007-1017.

Ibrahim, I. (2017). Green architecture challenges in the Middle East within different rating systems. Energy Procedia, 115(2017), 344-352.

Larsson, N. (2009). Integrated design process: theory, history and demonstrations. Available from: http://www.iisbe.org/node/88.

Lelhaj, R. \& Moosavi, M.S. (2014). Considering the effect of gender on women's understanding of architectural spaces, European Online Journal of Natural and Social Sciences, 3 (4), 520-533. Openly accessible at http://www.european-science.com.

Stern, N. H. (2007). The economics of climate change: the stern review. Cambridge. Great Britain. Cambridge University Press.

Stren, R., Polese, M. (2000). The Social Sustainability of Cities, Diversity and the Management of Change. Toronto: University Press.

Turner, C. (2005). Survey of green building plus green building in K-12 and higher education. New York: Turner Green Building. Retrieved December 24, 2013, from http://www.turnerconstruction.com/content/files/Green\%20Market\%20Barometer\%202005.

Zahedian, E. \& Moosavi, M.S. (2013). A morphological approach to characterization of urban space in historical structure of cities in Iran, J. Appl. Environ. Biol. Sci., 3(10) 59-66.

Zimmerman, A. (2006). Integrated Design Process Guide. Vancouver BC Canada Housing and Mortage Corporation.

Vandermeulen, V., Verspecht, A., Vermeire, B., Van Huylenbroeck, G., \& Gellynck, X. (2011). The use of economic valuation to create public support for green infrastructure investments in urban areas. Landscape and Urban Planning, 103(2): 198-206. 